\title{
Garap Rujak-Rujakan dalam Sindhènan Gaya Surakarta
}

\author{
Suyoto ${ }^{1}$ \\ Jurusan Karawitan, Fakultas Seni Pertunjukan, Institut Seni Indonesia Surakarta
}

\begin{abstract}
The Work of Rujak-rujakan in Sindhènan of Surakarta-style. This research reveals the work of rujak-rujakan in the Surakarta style sindhènan. Some issues are explored in this research, which are related to the the work of rujak-rujakan, how to interpret balungan rujak-rujakan, and the function of rujak-rujakan in Surakarta-style sindhènan. These points are explained based on data on the presentation of musical instruments as factual data exploration media. Data collection was carried out by means of literature studies, interviews, and also as a participant-observer. The data collection was carried out by literature study, interviews, and also as a participant-observer. The analysis is carried out by reinterpreting the thoughts and experiences of the pengrawit through practical reality. The interpretation uses the interpretation method and working analysis. The explanation and getting conclusions are carried out by the inductive method. The results obtained are that the rujak-rujakan is included in the shredded category, which has a complementary and varied function. There are four rujak-rujakan models: rujakrujakan with a descending melody, rujak-rujakan with an upward song, rujak-rujakan with kempyung melody sèlèh, and rujak-rujakan with flat tones. Céngkok rujak-rujakan can be applied to melody compositions that reflect the core of the rujak-rujakan melody. So if there is a balungan melody that reflects the melody rujak-rujakan, then a pesindhèn can fill the balungan with céngkok rujakrujakan. Rujak-rujakan is facultative, but its presence gives color or variety to the sindhènan.

Keywords: rujak-rujakan; abon-abon; sindhènan
\end{abstract}

\begin{abstract}
ABSTRAK
Tulisan ini mengungkap garap rujak-rujakan di dalam sindhènan gaya Surakarta. Beberapa persoalan yang digali terkait dengan garap rujak-rujakan, cara menafsir balungan garap rujak-rujakan, dan fungsi rujak-rujakan dalam sindhènan gaya Surakarta. Pemaparan didasarkan pada data penyajian karawitan sebagai media eksplorasi data secara faktual. Pengumpulan data dilakukan dengan cara studi pustaka, wawancara, dan juga sebagai partisipant observer. Analisis dilakukan dengan menafsirkan kembali pemikiran dan pengalaman pengrawit yang diperoleh melalui realita pragmatik. Penafsiran digunakan metode interpretasi dan analisis garap. Pemaparan dan penarikan kesimpulan dilakukan dengan metode induktif. Hasil yang didapatkan adalah bahwa rujak-rujakan termasuk pada kategori abon-abon yang memiliki fungsi sebagai pelengkap dan variatif. Terdapat empat jenis model rujakrujakan yaitu rujak-rujakan dengan alur melodi turun, rujak-rujakan dengan alur melodi naik, rujakrujakan dengan sèlèh melodi kempyung, dan rujak-rujakan dengan nada sèlèh flat. Céngkok rujakrujakan dapat diterapkan pada susunan melodi yang mencerminkan inti lagu rujak-rujakan. Jadi jika ada susunan melodi balungan yang mencerminkan lagu rujak-rujakan, maka seorang pesindhèn dapat mengisi balungan tersebut dengan céngkok rujak-rujakan. Rujak-rujakan bersifat fakultatif, tetapi kehadirannya memberi warna atau variatif pada sajian sindhènan.
\end{abstract}

Kata kunci: rujak-rujakan; abon-abon; sindhènan

\section{Pendahuluan}

Sindhèn berasal dari kata "sendhu" dan "ing". Sendhu memiliki pengertian memotong atau nyelani. Dalam suatu percakapan sering orang lain memotong percakapan itu, dan itulah yang dinamakan nyendhu. Kedua kata sendhu dan ing digabung menjadi sendhuing, bergeser menjadi

\footnotetext{
Alamat korespondensi: Jurusan Karawitan, Fakultas Seni Pertunjukan, Institut Seni Indonesia Surakarta. Jalan Ki Hadjar Dewantara No 19, Jebres, Kota Surakarta. E-mail: suyotoskar@gmail.com; HP.: 085728417111.
} 
sendhon. (Darsono, 2008). Sindhèn di masyarakat biasa juga disebut dengan pesindhèn, swåråwati, waranggånå, seniwati, bahkan di wilayah tertentu ada yang menyebut lèdhèk. Sindhèn juga sebuah kata kerja yang berarti menyanyi solo dalam karawitan Jawa (Suyoto, 2016). Sindhèn dalam dunia karawitan gaya Surakarta memiliki peranan penting, kedudukan sindhèn dalam karawitan setara dengan ricikan garap ngajeng (Suraji, 2005). Dikuatkan dalam pernyataan Supanggah, bahwa Supanggah membuat sebuah klasifikasi instrumen berdasarkan fungsi musikal dan memasukkan sindhèn pada kategori ricikan garap ngajeng (Supanggah, 2002). Klasifikasi lain juga diajukan oleh Sumarsam, klasifikasi yang ditawarkan ada tiga, yakni melodi, time (irama), dan stucture (Sumarsam, 2003). Sumarsam memasukkan sindhèn ke dalam klasifikasi kelompok melodi pada kategori elaboration. Beberapa klasifikasi tersebut mendudukkan sindhèn pada kategori garap, sehingga sindhèn memiliki peranan yang sangat penting dalam membangun suasana musikal sebuah gending. Vokal merupakan bagian yang berkaitan erat dengan kualitas seni karawitan (Budiarti, 2013). Di dalam karawitan secara lisan memiliki potensi reinterpretasi (Subuh, 2016).

Sindhènan adalah lagu vokal tunggal dalam karawitan yang disajikan secara melodis dengan mengacu pada kerangka (balungan) gending, baik yang menggunakan wangsalan maupun menggunakan cakepan khusus. Menurut jenisnya sindhènan dibagi menjadi dua kelompok, yaitu: sindhènan umum dan sindhènan khusus. Sindhènan umum adalah sindhènan yang menggunakan wangsalan sebagai teks pokok dan abon-abon sebagai pelengkap, yang selanjutnya disebut sindhènan srambahan. Sindhènan khusus adalah sindhènan yang menggunakan cakepan atau lagu khusus. Oleh karena khususnya itu, maka tidak dapat digunakan pada gending lain. Contoh: sindhènan gawan, sindhènan sekar, jineman, dan palaran. Sindhènan gawan merupakan jenis sindhènan yang cakepannya menyebut nama gending tertentu secara jelas atau lagu dan cakepannya telah menjadi satu kesatuan dengan gendingnya, sehingga tidak bisa digunakan pada gending yang lain (Suyoto, Timbul Haryono, 2015). Gending yang dibentuk dari tembang macapat selalu terdapat lagu sindhènan pokok yang berasal dari lagu tembang macapat yang menjadi dasar pembentuknya (Sugimin, 2005). Sedangkan sindhènan Sekar merupakan puisi Jawa yang penyajiannya dilagukan menggunakan laras pélog dan sléndro dengan aturan tersendiri baik lagu maupun teks (Suyoto, 2016). Cakepan yang digunakan dalam sindhènan adalah wangsalan dan abon-abon. Wangsalan sebagai teks pokok, sedangkan abon-abon adalah di luar teks pokok yang sifatnya sebagai pelengkap (Suyoto, 2016). Berdasarkan jumlah suku kata yang digunakan, wangsalan dibagi menjadi beberapa jenis yaitu; (1) wangsalan 4; (2) wangsalan 8; (3) wangsalan 12.

Wangsalan adalah semacam puisi tradisi Jawa, susunan kalimatnya tertata menurut suku kata yang telah ditentukan dan di dalam kalimat tersirat pertanyaan dan jawaban yang terselubung. Wangsalan terbagi menjadi dua bagian, bagian pertama disebut cangkriman atau teka-teki, sedangkan bagian kedua merupakan jawaban dari teka-teki sebelumnya. Dalam sindhènan terdapat beberapa jenis wangsalan diantaranya: (1) wangsalan rangkep, (2) wangsalan låmbå, (3) wangsalan memet, (4) wangsalan èdi pèni, dan (5) wangsalan padinan. Wangsalan Sindhènan srambahan selain menggunakan wangsalan juga menggunakan abonabon atau isèn-isèn yaitu teks yang berwujud katakata indah yang berfungsi sebagai pelengkap dalam sindhènan untuk mencukupi kebutuhan ukuran satu kalimat lagu tiap gåtrå dalam gending (Suyoto, 2016).

Abon-abon dalam kamus Bausastra Jawa dapat diartikan ubå rampé atau pelengkap (Atmodjo, 1987). Kata yang digunakan sebagai abonabon biasanya berupa sebutan identitas orang, pencandraan seseorang, baik laki-laki maupun perempuan, kata-kata kiasan yang kadang tidak dimengerti maknanya. Fungsi lain abon-abon adalah sebagai bumbu, penyedap, dan pemanis dalam sindhènan. Pesindhèn ibarat juru masak, harus pandai-pandai meramu bumbu, agar masakan terasa sedap. Terlalu banyak bumbu mungkin juga tidak enak, dan sebaliknya kurang bumbu juga tidak enak. Demikian halnya dalam sindhènan, terlalu banyak isèn-isèn juga tidak enak. Penempatan abon-abon tergantung pada kecerdasan 
seorang sindhèn dalam menafsir dan menerapkan isèn-isèn secara tepat sesuai alur melodi dan karakter gending. Lagu abon-abon disesuaikan dengan sèlèh pada akhir gåtrå dalam gending. Wangsalan memiliki tempat sendiri-sendiri.

Berdasarkan fakta musikal dalam penggarapan gending, dapat diketahui bahwa garap rujakrujakan bukanlah tanda musikal yang bersifat fisik semata. Garap tersebut terkait erat dengan pengetahuan, keterampilan, dan rasa (Aji, 2019). Langkah menggali konsep musikal ini berdasarkan empirical practices, sebagai peristiwa musikal dalam karawitan Jawa yang didasari pada pengalaman empirik para empu/seniman karawitan (Hastanto, 2012). Konsep kebudayaan dapat didefinisikan sebagai keseluruhan cara bertingkah laku manusia dalam kehidupannya yang menjadi suatu identitas (Nursulistiyo, 2019). Hal tersebut secara keilmuan belum banyak mendapat perhatian, pengrawit mayoritas hanya sadar dalam melakukan tetapi tidak sadar mengenai konsep-konsep yang ada di dalamnya. Sifat musik gamelan adalah gotong royong, artinya garapan ricikan satu dengan yang lain saling mengisi, saling merespon, dan saling menginspirasi (Teguh, 2017). Memang, musik dan aspek-aspek atau tingkah laku lainnya dalam kehidupan manusia memiliki keterkaitan, sehingga pemahaman mengenai suatu kebudayaan dapat dicapai antara lain lewat studi terhadap musiknya (Irawati, 2016).

\section{Metode Penelitian}

Terkait dengan persoalan di dalam penelitian ini, perlu ditetapkan prosedur elemen-elemen metodis berupa: (1) jenis data, (2) sumber data, (3) pengumpulan data, (4) pengolahan data, dan (5) analisis data. Di dalam pengumpulan data ditetapkan menggunakan perspektif emic etic. Adapun analisis menggunakan metode deskriptif analisis.

Emic yang dimaksudkan dalam keperluan penelitian ini bukan sebatas penilaian atau sudut pandang dari pêngrawit. Tetapi lebih kepada perasaan-perasaan yang ditimbulkan oleh pengetahuan empirik para pêngrawit. Misalnya, bagaimana sindhèn menafsirkan notasi balungan menggunakan rujak-rujakan, tentunya hal tersebut berdasarkan akumulasi pengalaman selama menjadi seorang pêngrawit berdasar atas garap gending secara konvensional.

Etic bukan sekedar sudut pandang peneliti, tetapi sudut pandang dari hasil pikiran logis. Maksudnya adalah setiap pernyataan yang dibuat terkait dengan garap rujak-rujakan di dalam garap gending, selalu berdasarkan atas realitas pragmatik. Hasil pemikiran tidak bersifat imajinatif. Kedua perspektif tersebut digabungkan untuk memahami dan mendapat kejelasan mengenai objek penelitian secara tuntas.

Penelitian ini tidak akan terjadi tanpa adanya suatu persoalan yang menarik untuk dikaji secara mendalam. Oleh sebab itu, langkah penelitian yang ditempuh adalah (a) mengidentifikasi céngkokcéngkok berdasarkan alurnya, mengidentifikasi rujak-rujakan menurut faktor-faktor pembentuknya, sehingga menghasilkan jenis-jenis céngkok rujak-rujakan. Selanjutnya dilakukan (b) klasifikasi. Berdasarkan jenis céngkok maka dapat diklasifikasi jenis rujak-rujakan menurut faktor pembentuknya dan sifatnya. Selanjutnya (c) studi pustaka merupakan langkah yang sangat fleksibel, penerapannya dapat dilakukan kapan saja dan bersamaan dengan langkah yang lain. Baik saat pengamatan langsung dan juga eksperimen. Pengamatan secara keseluruhan pada dasarnya merupakan upaya untuk mencari data secara aktual mengenai garap rujak-rujakan di dalam relitas pragmatik.

Setelah langkah di atas dilakukan, (d) deskripsi data ditempuh sebagai tindak lanjut setiap pengamatan dan wawancara usai dilakukan. Deskripsi data berhubungan dengan pemindahan atau transkripsi dari data berupa rekaman audiovisual hasil pengamatan ataupun wawancara ke dalam bentuk tulisan. Alih media yang dilakukan bertujuan untuk memilah data guna memudahkan proses analisis selanjutnya.

Data yang bersumber dari wawancara ditranskrip sesuai dengan rekaman. Penuturan verbal dari narasumber merupakan pengungkapan yang lebih berhubungan dengan pengetahuan yang mereka miliki. Tentunya, data dari beberapa narasumber memiliki adanya kesamaan dan juga 
perbedaan. Untuk itulah penting adanya proses klasifikasi atau pengelompokan data berdasarkan kesamaan atau perbedaannya. Dari sinilah diketahui perihal yang harus diperdalam kembali melalui wawancara ulang.

Jenis data yang diperoleh merupakan simbolisasi atas gagasan yang mewujud melalui elaborasi pengetahuan, keterampilan, dan rasa. Secara tidak langsung, proses interpretasi juga terjadi pada tahapan ini. Adanya pemisahan antar fenomena musikal serta hubungan fungsionalnya dilakukan untuk mendapatkan faktor pembentuk dan capaian pada garap rujak-rujakan. faktor terjadinya rujak-rujakan akan didapatkan secara utuh setelah proses analisis data dilakukan. Dengan demikian, tahapan ini merupakan usaha penguraian fenomena musikal sebagai salah satu simbol untuk mengetahui apa yang disimbolkannya.

Setelah data ditranskripsi, maka selanjutnya adalah (e) reduksi data. Proses reduksi data dilakukan dengan memilahkan antara data yang relevan dan yang tidak relevan dengan kebutuhan penelitian. Data yang relevan dipertahankan untuk proses analisis data selanjutnya, sedangkan data yang tidak relevan dipilahkan secara tersendiri. Sehingga, proses tersebut menghasilkan data yang benar-benar relevan dengan kebutuhan penelitian.

Sebagai upaya memperoleh kebenaran data secara utuh, maka dilakukan (f) validasi data sebagai sarana pengkajian ulang terhadap kebenaran data yang telah didapatkan. Cara validasi data yang dilakukan disesuaikan dengan jenis data yang telah didapatkan. Untuk jenis data musikal, validasi data dilakukan dengan cara mencermati kembali data yang telah didapatkan dalam bentuk rekaman dan juga mengadakan eksperimen ulang. Tipikalitas data musikal yang bersifat kinetis mengharuskan tergelarnya realitas pragmatik untuk menemukan dan memilah data yang relevan dengan kebutuhan penelitian.

Jenis data berupa konsep-konsep musikal, validasi dilakukan dengan wawacara ulang kepada pihak terkait mengenai pencarian data yang dilakukan oleh peneliti berdasarkan hasil wawancara sebelumnya. Selain itu, adanya penambahan pihak lain sebagai narasumber merupakan upaya validasi data dengan metode trianggulasi. Pengayaan informasi akan membantu terwujudnya keabsahan data di dalam penelitian. Pengkajian ulang bukubuku yang telah digunakan sebagai referensi juga termasuk di dalam upaya validasi data. Pemahaman ulang mengenai pernyataan tertulis yang telah dikutip sebelumnya, merupakan hal yang penting untuk dilakukan agar tidak terjadi kesalahan dalam menafsir pernyataan yang dianggap mendukung penelitian.

\section{Jenis dan Peran Abon-abon}

Abon-abon berdasarkan jenisnya memiliki bermacam-macam variasi, ada yang menggunakan pencandraan, sebutan orang, kata klise, dan kalimat purwåkanthi. Abon-abon dalam penerapannya terletak pada alur lagu sèlèh ringan (padhang) dan alur melodi nggantung. Setiap abon-abon tidak dapat diterapkan pada semua susunan melodi balungan tersebut. Penempatan abon-abon selalu mempertimbangkan tempat dan alur melodi balungan, sehingga mempengaruhi berapa suku kata yang harus digunakan dalam menempatkan abon-abon. Penempatan abon-abon tepatnya ketika terdapat gåtrå-gåtrå yang tidak berisi wangsalan, yaitu: plèsèdan, gåtrå ganjil, dan gåtrå genap yang tidak mempunyai kesan rasa sèlèh (Suraji, 2005).

Kedudukan, peran, dan fungsi sindhènan di dalam karawitan tidak dapat dikesampingkan (Saraswati, 2013). Abon-abon memiliki fungsi sebagai pelengkap dalam sindhènan, namun pada kasus tertentu abon-abon memiliki peran yang cukup penting dalam sebuah sindhènan, yaitu abon-abon memiliki peran sebagai penguat melodi balungan.

Tabel 1: Jenis Abon-abon. (Sumber: Suyoto)

\begin{tabular}{|c|c|c|c|c|}
\hline No & Pencandraan & $\begin{array}{l}\text { Sebutan } \\
\text { Orang }\end{array}$ & $\begin{array}{l}\text { Kata } \\
\text { Klise }\end{array}$ & Purwåkanthi Swara \\
\hline \multicolumn{2}{|c|}{ 1. wong kuning } & råmå & gonès & $\begin{array}{l}\text { rujak nanas pantes diwadahi gelas, } \\
\text { tiwas-tiwas nglabuhi wong ora welas }\end{array}$ \\
\hline \multicolumn{2}{|c|}{ 2. wong manis } & ramané dhéwé & nènès & $\begin{array}{l}\text { rujak uni rujaké wong èdi pèni, } \\
\text { ngadi-adi labeté wong oleh ati }\end{array}$ \\
\hline \multicolumn{2}{|c|}{ 3. wong bagus } & bapakné tholé & yå gonès & $\begin{array}{l}\text { rujak krai rujaké wong merak ati, } \\
\text { angastuti labeté wong dadi ati }\end{array}$ \\
\hline \multicolumn{2}{|c|}{ 4. gandes luwes sasolahé } & yå ndhuk & yå nènès & $\begin{array}{l}\text { rujak kawis rujaké wong ayu manis, } \\
\text { nora lamis labeté wong wus winasis }\end{array}$ \\
\hline \multicolumn{2}{|c|}{ 5. anteng tajem polatané } & yå mas & & $\begin{array}{l}\text { rujak rawé kumranyas nggateli lambe, } \\
\text { dhemen ngamé tan noleh githoké dhéwé }\end{array}$ \\
\hline \multicolumn{2}{|c|}{ 6. gonas ganès wicarané } & radèn & & $\begin{array}{l}\text { rujak jagung rujaké wong kumalungkung, } \\
\text { lengkung-lengkung serengé tansah } \\
\text { ginunggung }\end{array}$ \\
\hline \multicolumn{2}{|c|}{ 7. trithal-trithil kedhèpané } & $\begin{array}{l}\text { Mas-masku } \\
\text { dhéwé }\end{array}$ & & $\begin{array}{l}\text { jenang majjå pantes dinahar sang Dwijå, } \\
\text { éwuh ayaa ngladeni wong tan prasåjå }\end{array}$ \\
\hline \multicolumn{2}{|c|}{ 8. rompyoh-rompyoh sesinomé } & & & $\begin{array}{l}\text { madu mångsả dinahar langkung miråså, } \\
\text { dèn santoså mring cobaning kang kawåsåa }\end{array}$ \\
\hline \multicolumn{2}{|c|}{ 9. sripat-sripit lèmbèhané } & & & $\begin{array}{l}\text { gudhang luntas cinaruban roning adas, } \\
\text { nadyan lugas dhasaré priyayi bregas }\end{array}$ \\
\hline 10. & & & & $\begin{array}{l}\text { rujak rau gelondhong isiné madu, } \\
\text { ajaja kliru sing tengah bakal duwèku }\end{array}$ \\
\hline
\end{tabular}


Abon-abon sebagai pengisi kekosongan juga memiliki peran sebagai penguat karakter gending, sehingga gending menjadi hidup. Karena notabene abon-abon memiliki fungsi sebagai pemanis, maka abon-abon bersifat fleksibel dalam ranah penempatan. Banyak susunan melodi balungan yang tidak dapat direfleksikan oleh sindhènan wangsalan, karena wangsalan memiliki aturan yang ketat dalam hal jumlah suku kata, sedangkan abon-abon memiliki beberapa alternatif yang dapat digunakan. Oleh karena itu, ada beberapa susunan melodi balungan yang hanya dapat direspon menggunakan abonabon. Dalam contoh pada ladrang Pakumpulan laras sléndro pathet sångà berikut.

Ladrang Pakumpulan kempul pertama rambahan ke II

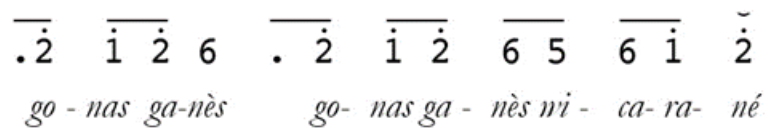

Contoh di atas membuktikan bahwa peran abon-abon dalam merespon melodi balungan sangatlah penting, abon-abon juga terbukti bersifat fleksibel dalam merespon alur melodi balungan. Susunan melodi balungan di atas tidak mungkin direspon menggunakan wangsalan, karena wangsalan terpathok dalam jumlah suku kata dan wangsalan tidak dapat merespon susunan balungan yang berbentuk ritmis. Wangsalan hanya dapat merespon susunan balungan yang bersifat sèlèh (tidak nglagu). Garap yang dinamis salah satunya dalam garap céngkok sangat berperan dalam membangun suasana gending (Supanggah, 2009). Secara umum, dalam karawitan memiliki unsur nada, notasi, irama, lagu, teknik, dan ritme (Surya Osada, 2015). Ritmis merupakan salah satu aspek musikologis yang berhubungan dengan sifat musikalitas (Yasa, 2017). Di sinilah peran dan pentingnya sebuah abon-abon dalam sindhènan gaya Surakarta. Peran seorang sindhèn adalah ikut membangun suasana gending dengan cara merespon susunan melodi balungan. Dengan demikian dapat dikatakan abonabon memiliki kedudukan yang sama pentingnya dengan wangsalan dalam membangun suasana/ karakter gending. Secara fisika, ketika pengrawit memainkan gamelan, mereka memindahkan energi kinetik dari tubuhnya pada instrumen gamelan (Prasetya, Haryono, \& Simatupang, 2016).
Penerapan abon-abon dalam sebuah gending tentunya memiliki aturan-aturan secara normatif. Seperti yang tela dijelaskan di atas bahwa abonabon secara normatif ditempatkan pada balungan nggantung dan melodi sèlèh ringan (padhang). Pada kasus tertentu, abon-abon dapat ditempatkan pada susunan melodi apa saja, termasuk pada melodi balungan sèlèh, dengan mempertimbangan alur melodi balungan dan garap ricikan ngajeng (rebab dan gendèr). Sindhènan baku dan sindhènan abonabon tidak pernah terlepas dari ricikan garap, ricikan tersebut merupakan sebuah ricikan yang memiliki tugas menggarap balungan gendhing, sehingga menjadi sebuah satu kesatuan garap yang harmoni. Hubungan paling erat dalam ricikan adalah rebab dan sindhèn, dikarenakan ricikan rebab memiliki peran sebagai pamurba lagu yang berarti mengendalikan alur lagu melodi balungan.

\section{Abon-abon Rujak-rujakan}

Abon-abon memiliki satu jenis yang cukup menarik dan unik yaitu abon-abon jenis rujakrujakan. Rujak-rujakan merupakan abon-abon dengan ciri menggunakan susunan kalimat purwåkanthi swåra. Penempatan atau penggunakan rujak-rujakan memiliki aturan yang berbeda dengan abon-abon yang lain, rujak-rujakan memiliki jumlah suku kata berbeda dengan yang lain. Abon-abon rujak-rujakan memiliki ciri khas lagu yang melekat pada teksnya, meskipun menggunakan cakepan yang tidak merepresentasikan rujak-rujakan, alur melodi céngkok rujak-rujakan tetap mencirikan bahwa itu melodi rujak-rujakan. Céngkok di dalam

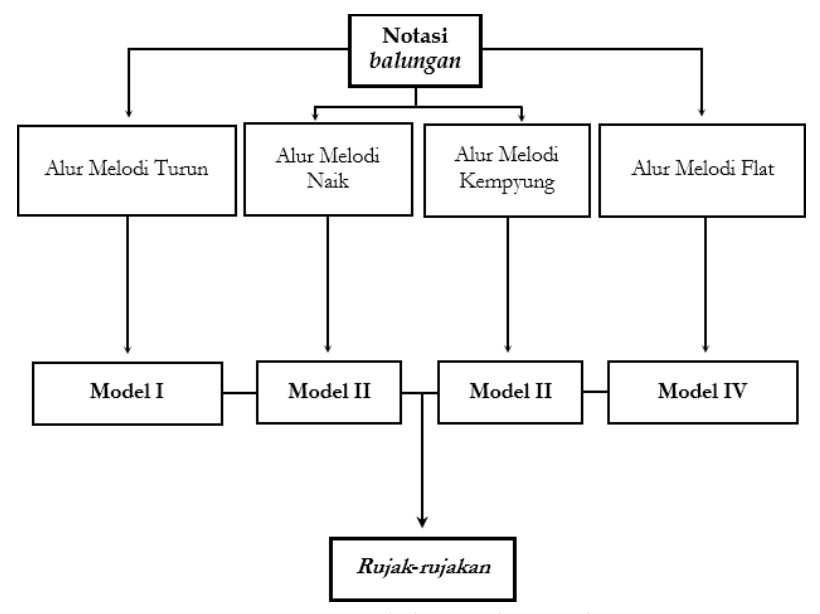

Bagan 1: Model rujak-rujakan. 
gending memiliki dua pengertian ; (1) céngkok yang berarti garap dan (2) céngkok yang berarti jumlah gong pada suatu gending (Martopangrawit, 1969). Sebagai sebuah sajian vokal, memiliki dua unsur yang saling terkait yakni lagu dan cakepan (Rahayu, 2018). Tembang yang ditulis dalam bentuk teks merupakan media berpikir dan merasa, merupakan media komunikasi estetik (Darmasti, 2011). Dalam melodi balungan, rujak-rujakan menjadi dua alur melodi sèlèh. Melodi balungan atau notasi balungan adalah hasil abstraksi gending yang divisualkan dalam bentuk lambang musikal, baik berupa angka, grafis, huruf, atau tanda lainnya (Hastuti, Khafi izh, 2016). Relasi antar balungan dalam sebuah gåtrå memiliki kedudukan yang sejajar dengan relasi padhang-ulihan dalam gending (Fitria, 2018). Berbeda dengan abon-abon yang lain, mayoritas hanya satu alur melodi. Tentunya terdapat aturan atau faktor khusus di mana rujak-rujakan harus diterapkan, karena tidak semua melodi balungan dapat diisi dengan abon-abon céngkok rujakrujakan. Diperlukan referensi yang cukup bagi seorang pesindhèn dalam menafsirkan melodi balungan untuk abon-abon céngkok rujak-rujakan.

Rujak-rujakan tidak dapat ditempatkan pada susunan melodi balungan yang sembarangan, karena rujak-rujakan sendiri memiliki ciri khas lagu. Alur lagu pada rujak-rujakan tidak hanya satu, terdapat beberapa céngkok lagu rujak-rujakan, meskipun berbeda alur lagunya tetapi inti dari alur lagunya tetap sama. Dapat dikatakan bahwa céngkok rujak-rujakan merupakan sebuah céngkok mati, dalam arti mati dalam sebuah céngkok bukan penerapannya. Secara penerapan rujak-rujakan tetap bersifat pasrèn atau penghias, karena céngkok rujak-rujakan termasuk dalam kategori abon-abon. Pasrèn dari kata dasar asri yang berarti indah, Istilah pasrèn juga digunakan Hastanto dalam mengklasifikasikan ricikan gamelan yang disebut dengan ricikan pasrèn atau pepaès yang berarti hiasan (Hastanto, 2009). Céngkok rujak-rujakan dibagi menjadi tiga model. Berikut merupakan contoh model alur melodi céngkok rujak-rujakan. Rujak-rujakan model I

Contoh 1 dalam laras sléndro manyurå

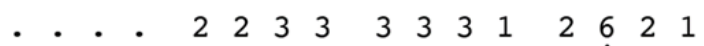

ru-jak na-nas pan-tes di- wa-dab-i ge-las,

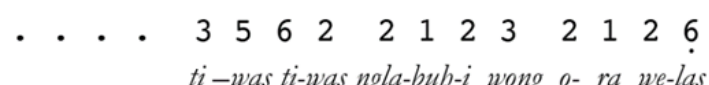

$t i$-was ti-was ngla-bub-i wong o- ra we-las

Contoh 2 dalam laras pélog nem

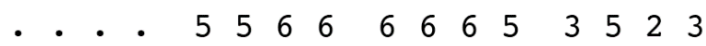

ru-jak na-nas pan-tes di-wa-dah-i ge-las,

- . 355555566532

ti-was ti-was ngla-buh-i wong o- ra we-las

Contoh 3 dalam laras sléndro sångå

•. . $\quad \begin{array}{llllllllllll}1 & 1 & 2 & 2 & 2 & 2 & 2 & 1 & 2 & 5 & 1 & 6\end{array}$

ru-jak na-nas pan-tes di-wa-dah-i ge-las,

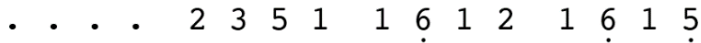

ti-was ti-was ngla-buh-i wong o- ra we-las

Contoh 4 dalam laras pélog barang

•. . 77766666777773

ru-jak na-nas pan-tes di-wa-dah-i ge-las,

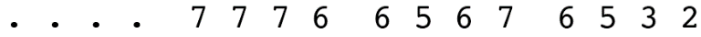

ti-was ti-was ngla-bub-i wong o- ra we-las

Rujak-rujakan pada model I merupakan jenis rujak-rujakan yang memiliki alur melodi turun secara berurutan. Sudah dijelaskan sebelumnya bahwa céngkok rujak-rujakan terdiri dari dua alur melodi balungan. Model I menjelaskan bahwa dua frasa merupakan alur melodi menurun. Dapat dilihat pada penjelasan di bawah ini:

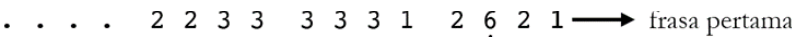

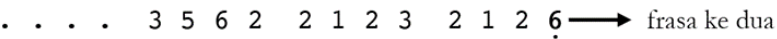

Ditunjukkan bahwa frasa pertama memiliki sèlèh pada melodi balungan 1, sedangkan frasa sèlèh kedua memiliki sèlèh 6 (ageng). Susunan melodi balungan 1 ke 6 (ageng) merupakan susunan melodi dengan alur menurun. Hal tersebut juga sama halnya pada contoh yang lain dalam model I. pada model I merupakan model rujak-rujakan yang paling sering dijumpai pada susunan melodi balungan. Mayoritas céngkok rujak-rujakan menggunakan alur melodi menurun.

Setiap susunan melodi balungan yang dapat digarap rujak-rujakan khususnya model I, selalu mencerminkan inti lagu dari rujak-rujakan itu sendiri, bahkan sèlèh pada melodi balungan sama persis dengan sèlèh pada céngkok rujak-rujakan. Dapat dilihat pada beberapa contoh analisis di bawah ini.

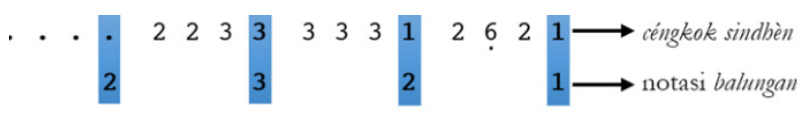




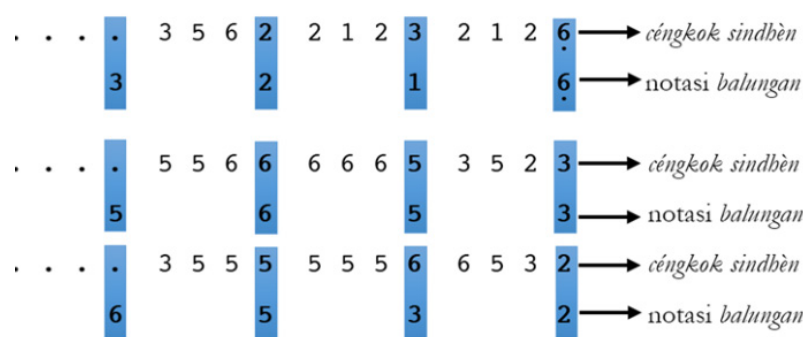

Contoh di atas merupakan penegasan bahwa susunan melodi balungan merefleksikan alur lagu céngkok rujak-rujakan. Setiap sabetan balungan terdapat korelasi dengan lagu rujak-rujakan. Model I merupakan susunan melodi balungan yang merefleksikan lagu rujak-rujakan dengan alur melodi balungan menurun. Dalam contoh susunan melodi balungan:

$23213216,56536532,76737632,2126$ 216̣, dst

Susunan melodi balungan dengan arah nada menurun, dengan catatan merefleksikan lagu rujakrujakan maka seorang pesindhèn dapat menafsirkan melodi balungan tersebut dengan garap rujak-rujakan. Secara garap gendèr melodi tersebut di garap dengan céngkok dua lolo kemudian tumurun. Rujak-rujakan model I di atas dapat ditemukan pada kasus gending: Pangkur, Sri Widada, Rujak Jeruk, Driyasmara, dan masih banyak gending lainnya.

Model I tidak hanya berlaku pada susunan melodi balungan mlaku, tetapi juga berlaku pada melodi balungan nibani. Dengan catatan melodi balungan nibani tersebut juga mempunya garap yang sama seperti balungan mlaku. Dalam contoh pada susunan balungan .6.5 (sléndro sanga), jika tafsir ricikan gendèr dan rebab menggunakan céngkok dua lolo kemudian tumurun, maka susunan melodi tersebut juga dapat berpotensi di garap rujakrujakan. Tentunya tetap mempertimbangkan yang lain (watak gending, irama, dan garap gending). Rujak-rujakan model II

Contoh 1 dalam laras sléndro

•. . $\begin{array}{rrrrrrrrrrrrr}2 & 2 & 2 & 2 & 6 & 6 & 6 & 1 & 2 & 3 & 6 & 2 & 1\end{array}$ ru-jak na-nas pan-tes di-wa-dah-i ge-las,

•. . 666666 i 26352 ti-was ti-was ngla-bub-i wong o- ra we-las

Rujak-rujakan model II merupakan jenis rujak-rujakan yang memiliki alur melodi naik. Frasa pertama dan kedua memiliki alur melodi naik yang nadanya berurutan. Dapat terlihat dengan penjelasan berikut ini.

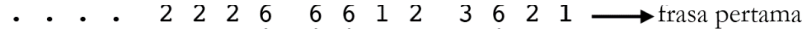
.. . 666666 i $263552 \longrightarrow$ frasa ke dua

Frasa pertama memiliki nada sèlèh 1, sedangkan pada frasa kedua memiliki nada sèlèh 2. Susunan melodi balungan dari nada 1 ke 2 memiliki alur melodi naik dengan nada berurutan. Model II ini juga terdapat pada beberapa repertoar gending, tetapi kehadirannya tidak sebanyak pada model I. Meskipun memiliki alur melodi naik, susunan balungannya tetap merefleksikan céngkok rujak-rujakan. Dapat dilihat pada analisis berikut ini.

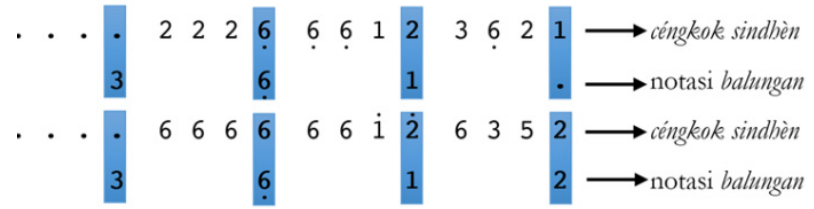

Terlihat jelas korelasi notasi balungan dengan céngkok sindhènan rujak-rujakan. Alur melodi balungan merefleksikan alur lagu rujak-rujakan. Model II merupakan contoh rujak-rujakan dengan alur melodi menurun dengan nada berurutan. Susunan melodi balungan di atas dapat ditemukan di Ladrang Mugi Rahayu. Garap ricikan gendèr dan rebab pada balungan tersebut adalah menggunakan céngkok dua lolo kemudian jarik kawung. Sehingga jika terdapat susunan melodi balungan seperti model II dengan garap ricikan yang sama, seorang pesindhèn dapat menafsirkan balungan tersebut menggunakan céngkok rujak-rujakan.

Rujak-rujakan model III

Contoh 1 dalam laras pélog nem

... $i$ i i i i i i 2 i 556 i ru-jak na-nas pan-tes di- wa-dah-i ge-las,

... $\quad$ i i i i $i$ i 2 i 65045

ti-was ti-was ngla-bub-i wong o- ra we-las

Rujak-rujakan model III merupakan jenis rujak-rujakan yang memiliki sèlèh kempyung (frasa pertama dan frasa ke dua). Pada model III ini frasa pertama memiliki nada sèlèh kempyungnya dari nada sèlèh frasa ke dua, baik kempyung atas maupun kempyung bawah. Dapat dilihat pada penjelasan berikut ini.

... i i i i i i i 2 i 56 i $\longrightarrow$ frasa pertama . . . i i i i $i$ i 2 i 65 4 $5 \longrightarrow$ frasa ke dua

Sèlèh nada frasa pertama adalah nada 1 (alit), sedangkan sèlèh frasa ke dua adalah nada 5. Nada 
1 dan nada 5 merupakan nada kempyung, kasus ini tergolong pada kasus kempyung atas. Selain kasus kempyung atas juga terdapat kasus kempyung bawah yang juga termasuk pada model III. Susunan melodi balungannya tetap merefleksikan alur lagu rujak-rujakan. Seperti analisis di bawah ini.

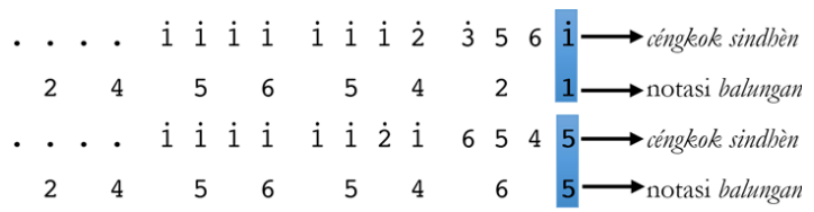

Terlihat korelasi antara céngkok rujak-rujakan dengan melodi balungan. Kasus seperti di atas terdapat pada Ladrang Sri Rejeki dan juga terdapat pada beberapa repertoar gending lainnya. Model III menjelaskan bahwa céngkok rujak-rujakan dengan nada sèlèh frasa pertama dan ke dua merupakan nada kempyung, baik kempyung atas maupun kempyung bawah.

\section{Rujak-rujakan model IV}

Contoh 1 dalam laras pélog nem

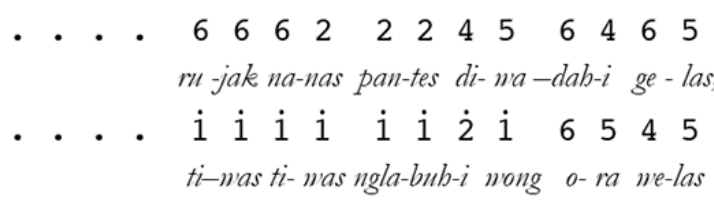

Contoh 2 dalam laras pélog barang

$$
\begin{aligned}
& \text { - . } 672365676563 \\
& \text { rii-jak na-nas pan-tes di-wa-dab-i ge-las, } \\
& \text { - . } 35672 \dot{3} 657653 \\
& \text { ti-was ti-was ngla-bub-i wong o- ra we-las }
\end{aligned}
$$

Rujak-rujakan model IV merupakan jenis rujak-rujakan dengan alur flat, dapat dikatakan flat atau lurus dikarenakan nada sèlèh frasa pertama dan ke dua sama. Dapat dijelaskan di bawah ini.

-.. $672365676563 \longrightarrow$ frasa pertama •. . $35672 \dot{2} 657653 \longrightarrow$ frasa ke dua

Frasa pertama memiliki nada sèlèh 3 dan frasa ke dua juga memiliki nada sèlèh 3, maka secara alur melodi nada sèlèh bersifat flat, berbeda dari model sebelumnya yang memiliki alur naik, turun, dan kempyung. Meskipun nada sèlèh flat tetapi alur lagu menuju sèlèh tetap merepresentasikan lagu céngkok rujak-rujakan. Korelasi melodi balungan dan melodi vokal juga terbentuk, dapat di lihat pada analisis berikut ini.

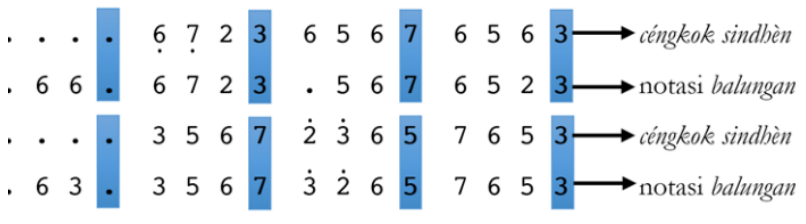

Korelasi antara céngkok sindhènan dan notasi balungan terlihat sangat jelas. Contoh kasus di atas dapat ditemukan pada Ladrang Wahana. Setiap alur melodi dan céngkok rujak-rujakan memiliki inti lagu yang sama. Kasus tersebut juga terdapat pada gending yang lain, tetapi kehadirannya tidak terlalu populer dalam gending. Model IV merumuskan bahwa céngkok rujak-rujakan dengan nada sèlèh yang flat.

\section{Kesimpulan}

Rujak-rujakan merupakan bagian abon-abon dari sindhènan. Penerapan rujak-rujakan bersifat fakultatif dan variatif, atau dapat dikatakan sebagai penghias gending, pelengkap gending, dan sebagai bahan variasi bagi seorang pesindhèn menafsirkan susunan melodi balungan. Selain sebagai pelengkap, rujak-rujakan sebagai abon-abon juga mempunyai peran sebagai pendukung karakter gending. Kehadirannya sangat penting dalam membangun suasana musikal. Rujak-rujakan secara musikal memiliki lagu sendiri, yang menjadikan sebuah ciri khas. Satu-satunya abon-abon yang memiliki lagu sendiri hanya rujak-rujakan. Abon-abon yang lain hanya sebatas mengikuti alur melodi balungan pada gending. Meskipun terkadang rujak-rujakan juga mengikuti alur melodi balungan, tetapi inti lagu dari rujak-rujakan tetap sama.

Terdapat empat model rujak-rujakan dilihat berdasarkan nada sèlèh setiap frasanya. Model I merupakan rujak-rujakan yang memiliki nada sèlèh menurun secara berurutan pada ke dua frasa yang digarap dengan céngkok dua lolo dan tumurun. Model II merupakan rujak-rujakan yang memiliki nada sèlèh naik secara berurutan pada ke dua frasa yang digarap dengan céngkok dua lolo dan jarik kawung. Model III merupakan rujak-rujakan yang memiliki nada sèlèh kempyung pada frasa pertama dan ke dua, baik kempyung atas atau kempyung bawah. Model IV merupakan rujak-rujakan yang memiliki nada sèlèh yang sama pada frasa pertama 
dan ke dua, dapat di katakan memiliki alur sèlèh yang flat atau lurus. Meskipun terdapat beberapa model rujak-rujakan, tetapi pada dasarnya memiliki inti lagu yang sama, hanya pengolahan sèlèh dan alur melodi yang berbeda.

Seorang pesindhèn dapat menafsiran melodi balungan model I-IV dengan garap sindhènan rujak-rujakan. Setiap melodi balungan yang merepresentasikan lagu rujak-rujakan, pesindhèn juga dapat menafsirkan balungan tersebut dengan sindhènan rujak-rujakan. Meskipun memiliki peran sebagai pelengkap, tetapi dibutuhkan referensi dan kecerdasan seorang pesindhèn untuk menafsirkan susunan melodi balungan dengan garap rujak-rujakan, sehingga dapat memperkuat atau mendukung karakter gending.

\section{Kepustakaan}

Aji, A. S. (2019). Konsep Mandheg dalam Karawitan Gaya Surakarta. Resital: Jurnal Seni Pertunjukan, 20(2), 81-95.

Atmodjo, P. (1987). Kamus Bahasa Jawa (Bausastra Jawa). Surabaya: Djojo Bojo.

Budiarti, M. (2013). Konsep Kepesindenan dan Elemen-Elemen Dasarnya. Harmonia: Journal of Arts Research and Education, 13(2), 147156.

Darmasti. (2011). Kidung Kandhasanyata Sebagai Ekspresi Estetik Pesinden Wanita Mardusari. Harmonia: Journal of Arts Research and Education, 11(2), 180-190.

Darsono. (2008). Konsep Dasar Sindhenan Dalam Karawitan. Keteg: Jurnal Pengetahuan, Pemikiran dan Kajian Tentang "Bunyi," 8(2), $1-19$.

Fitria, I. A. (2018). Balungan Ladrang Slamet Laras Slendro Pathet Manyura Ditinjau dari Konsep Mancapat. Resital: Jurnal Seni Pertunjukan, 19(3), 131-145.

Hastanto, S. (2009). Konsep Pathet dalam Karawitan Jawa. Surakarta: ISI Press.

Hastanto, S. (2012). Konsep Êmbat dalam Karawitan Jawa. Panggung: Jurnal Seni \& Budaya, 22(3), 225-350.

Hastuti, Khafi izh, dan S. (2016). Indentifikasi Fitur Melodi dalam Musik Gamelan Berdasarkan
Hubungan Asosiasi Antar-Notasi. Seminar Nasional Sistem Informasi Indonesia, hal. 47-54.

Irawati, E. (2016). Transmisi Kelentangan dalam Masyarakat Dayak Benuaq. Resital: Jurnal Seni Pertunjukan, 17(1), 1-18.

Martopangrawit. (1969). Pengetahuan Karawitan I. Surakarta: Dewan Mahasiswa Akademi Seni Karawitan Indonesia.

Nursulistiyo, E. (2019). Pemanfaatan Siter, Kendang, Saron, Kenong, dan Gender sebagai Media Pembelajaran Fisika. Jurnal Riset dan Kajian Pendidikan Fisika, 6(1), 5.

Prasetya, H. B., Haryono, T., \& Simatupang, L. L. (2016). Habitus, Ngêng, dan Estetika Bunyi Mlèsèt dan Nggandhul pada Karawitan. Paradigma: Jurnal Kajian Budaya, 1(2), 152.

Rahayu, S. (2018). Estetika Wangsalan dalam Lagu Sindhenan Karawitan Jawa. Gelar: Jurnal Seni Budaya, 16(1), 42-49.

Saraswati, B. A. (2013). Perjalanan hidup dan Kreatifitas Sang Pesindhèn. Dewa Ruci, 8(2), 157-177.

Subuh, S. (2016). Garap Gending Sekaten Keraton Yogyakarta. Resital: Jurnal Seni Pertunjukan, 17(3), 178-188.

Sugimin. (2005). Pangkur Paripurna (Kajian Perkembangan Garap Musikal). Surakarta: Sekolah Tinggi Seni Indonesia.

Sumarsam. (2003). Interaksi Budaya dan Perkembangan Musikal di Jawa. Yogyakarta: Pustaka Pelajar.

Supanggah, R. (2002). Bothekan Karawitan I. Surakarta: MSPI

Supanggah, R. (2009). Bothekan Karawitan II: Garap. Surakarta: ISI Press.

Suraji. (2005). Sindhenan Gaya Surakarta. Tesis Program Studi Pengkajian Seni Minat Musik STSI Surakarta, Surakarta.

Surya Osada, S. (2015). Etnomatematika dalam Titi Laras Dan Irama pada Karawitan Jawa. Prosiding Seminar Nasional Etnomatnesia, Universitas Sanata Dharma Yogyakarta, 475-481.

Suyoto. (2016). Carem: Puncak Kualitas Bawa dalam Karawitan Gaya Surakarta. Disertasi Program Studi Pengkajian Seni Pertunjukan 
dan Seni Rupa, UGM Yogyakarta.

Suyoto, Timbul Haryono, S. H. (2015). Estetika

Bawa dalam Karawitan Gaya Surakarta. Resital: Jurnal Seni Pertunjukan, 16(1), 36- 51.

Teguh. (2017). Ladrang Sobrang Laras Slendro
Patet Nem. Resital: Jurnal Seni Pertunjukan, 18(2), 103-112.

Yasa, I. K. (2017). Aspek Musikologis Gêndér Wayang dalam Karawitan Bali. Resital: Jurnal Seni Pertunjukan, 17(1), 46-59. 